\title{
The Nexus Between Good Governance Indicators And Human Development Index In Africa: An Econometric \\ Analysis
}

\author{
Paulos C. Tsegaw (PhD.) \\ Associate Professor, Department of Mathematics and Economics, Virginia State \\ University \\ 1 Hayden Drive, Virginia, 23806, USA \\ E-mail:ptsegaw@vsu.edu; paulos.chanie@gmail.com
}

Received: March 2, 2020 Accepted: March 23, 2020 Online published: April 1, 2020

doi:10.5296/jpag.v10i2.16598～URL: https://doi.org/10.5296/jpag.v10i2.16598

\begin{abstract}
This study examines the association between good governance indicators and the human development index in Africa. Accordingly, it uses the panel data of 49 African countries from 2000-2018 on the six World Bank governance indicators (WGIs) and the UNDP aggregate human development index (HDI). The data are analyzed using descriptive statistics and panel regression analysis. The descriptive statistical analysis shows that most of the countries that are scoring high in the governance indicators are also scoring high in the human development index. It also indicates that Africa's average score in all governance indicators from 2000-2018 ranges between $36.2 \%$ and $40.4 \%$, while the score for human development was $50.8 \%$. Using a one-year moving average, the calculated improvement rates for the eighteen years in all the governance and human development indicators were meager. The finding from the panel regression analysis attests only the three good governance indicators - the rule of law, regulatory quality, and political stability and absence of violence - are significantly and directly associated with the human development index. The finding implies that policy makers in African countries should give emphasis on these three good governance indicators to augment their human development effort.
\end{abstract}

Keywords: good governance, human development, Africa, panel data regression

\section{Introduction}

For almost three decades after independence, many African countries followed the policy of centralization in the management of their socio, economic, and political systems. 
Centralization in Africa, however, brought about weak and fragile states; brutal, autocratic and corrupt governments; poverty and backwardness among the majority of the population; wastage of resources and corruption; regional and ethnic inequalities and conflicts; and poor technological, political and economic advancements (Wunsch and Olowu, 1990). World Bank (1989:3) reiterated that the western model, namely the modernization strategy, copied by African governments resulted in poorly designed, top-down, and interventionist development policies and strategies that resulted in failed economic and political systems. UNDP (1990:5) in its Human Development Report also stated that "between 1979 and 1985 the number of African people below the poverty line increased by almost two-thirds, compared with an average increase of one-fifth in the entire developing world".

Since the beginning of the 1990s, however, different approaches to development intended to reverse the legacy of centralization were introduced in many African countries. The two fundamental approaches were: the human development approach and the governance approach to development. Underscoring Africa's predicament in the 1970s and 1980s, UNDP's Human Development Report (1990:1) proposed the human development approach to development, and considers development as "a process of enlarging people's choices to live a long and healthy life, to be educated and to have access to resources needed for a decent standard of living; including political freedom, guaranteed human rights and personal self-respect." The report (1990:10) provided the three human development indicators that are "approximation for capturing the many dimension of human choices" and include life expectancy index, education index, and GNI index. During the same period, the World Bank (1989:60) also introduced the governance approach to development and stated that "Underlying the litany of Africa's development problems is a crisis of governance." This report defined governance as "the exercise of political power to manage a nation's affairs"; and suggested six indicators, namely control of corruption, voice and accountability, governance effectiveness, political stability and absence of violence, regulatory quality, and the rule of law.

Researchers and practitioners have been using the Human Development Index (HDI) and World Governance Indicators (WGI) to measure and analyze, interalia, improvements in the standard of living, health and education as well as progresses in public institutions capacity to conduct public affairs and manage public resources. Various studies used the indicators to measure and analyze signs of progress in and relationships among different social, economic, and political issues. Some of them include studies on the nexus between human development and economic growth (Chikalipah and Makina, 2019; Bundala, 2012); human development and fiscal Consolidation (Agnello et al., 2018); human development and Globalization (Asongu and Nwachukw, 2016); human development and level of economic development (Eren et al., 2014); and Poverty Reduction and Human Development (Arimah, 2004). Likewise, some studies analyzed the nexus between governance and foreign aid and instability in Africa (Asongu and Nnanna, 2019); government effectiveness and economic growth (Alam et al., 2017), governance and poverty (Kwon and Kim, 2014); governance and economic growth and income inequality (Fayissa and Nsiah, 2013); as well as governance and democracy (Ishiyama, 2019). 
For the last two decades, studies also analyzed the relationship between governance and human development. Some of them include studies on relationships between good governance and human development in India (Rudra \& Sanyal, 2011), in South Asia (Khan, 2015), as well as in the 33 Europian Union Countries (Keser and Gökmen, 2017). A critical study on the link between governance and human development in Africa was the article entitled: "good governance as a foundation for sustainable human development in sub-Saharan Africa" (Davis, 2017). The later study suggested that the three WGI indicators: government effectiveness, political stability and absence of violence, and controlling corruption have a significant impact on improving human development efforts in sub-Saharan Africa. This study, however, used only one-year data.

As indicated above, while some studies analyzed the relationship between governance, human development, and various political, economic and social issues, there are only a few studies that investigate the relationship between human development and good governance in Africa using longitudinal data encompassing almost all the African countries. Accordingly, this study will try to fill that gap and investigate the association between the six governance indicators and human development in Africa using the panel data from 2000 - 2018 for 49 African countries. Descriptive and inferential statistics will show which governance indicators are associated or linked with the human development index. The intent here is not to test a specific theoretical explanation on the relationship between good governance and human development or to find a causal relationship between governance and human development; instead, the intent here is to engage in empirical research that explores which of the good governance indicators are linked or associated with human development index. The finding will help policy makers in African countries to understand which of the governance indicators should be given relative emphasis in their attempt to improve human development.

In this article, first, the concepts of good governance and human development will be highlighted. Secondly, the empirical literature on the relationship between governance indicators and the human development index will be assessed. Thirdly, the methodology will be presented, followed by the discussion on the findings of the descriptive and panel regression data analyses on the association between good governance indicators, and the human development index.

\section{Highlights on Good Governance and Human Development Indicators}

\subsection{Good Governance}

Good governance had become a prominent concept when the World Bank declared that "the litany of Africa's development problems" is "a crisis of governance" (World Bank, 1989). Since then, multilateral and bilateral organizations have given different definitions. Gisselquist (2012) provided a summary of the ten organizations working definitions of good governance. To mention some, the UNDP considers good governance as a governing system that is capable, responsive, inclusive, and transparent. The UN attributes good governance as instrumental in promoting equity, participation, pluralism, transparency, accountability, and the rule of law, in a manner that is effective, efficient, and enduring. The World Bank takes good governance as a combination of transparent and accountable institutions, persuasive 
skills and competence, and a fundamental willingness to do the right thing. Organization for Economic Cooperation and Development (OECD) defines governance to include accountability, transparency, efficiency and effectiveness, responsiveness, and forward vision (Ibid).

The above definitions show the interaction between elements of good governance and managing the socio-political and economic affairs of a given country. Various organizations also provide different governance indicators. Some of them include: African Peer Review Mechanism (APRM), the Moe Ibrahim Index of African Governance, the World Bank's World Governance Indicators (WGIs), the Transparency International's Corruption Perceptions Index (CPI), and the World Bank/International Finance Corporation's Doing Business Indicators. Among these indicators, the most widely used indicators are the World Bank Governance Indicators; and this study will use the same.

The World Bank Governance indicators developed by Kaufman, Kraay, and Zoido-Lobaton (1999) are in alignment with the definitions of good governance. These six indicators capture perceptions on:

- Voice and Accountability: citizens participation in selecting their government, freedom of expression, freedom of association, and free media;

- Political Stability and Absence of Violence/Terrorism: the likelihood that the government will be destabilized or overthrown by unconstitutional or violent means, including politically motivated violence and terrorism;

- Government Effectiveness: the qualities of public services, the quality of the civil service and the degree of its independence from political pressures, the quality of policy formulation and implementation, and the credibility of the government's commitment to such policies;

- Regulatory Quality: government ability to formulate and implement sound policies and regulations that permit and promote private sector development

- Rule of Law: agents confidence in and abide by the rules of society, and in particular the quality of contract enforcement, property rights, the police, and the courts, as well as the likelihood of crime and violence; and

- Control of Corruption: the extent to which public power is exercised for private gain, including both petty and grand forms of corruption, as well as "capture" of the state by elites and private interests (Ibid).

These six indicators are assigned a score (value) ranging from -2.5 (a very low score) to + 2.5 (a very high score). Based on the scores, each country will have a percentile rank, ranging from 0 to 100 , where the higher the score, the better the national performance on that indicator (Kaufmann, Kraay and Mastruzzi, 2008).

The use of governance indicators has been debatable among academics and practitioners. There are questions on the reliability of the sources for constructing the indicators, number of sources used, measuring capacity of the sources, the margin of error on differences between countries and between different times, as well as transparency and selection bias of 
measurements. For instance, Arndt And Oman (2006) argued that the WGI lacked transparency and comparability over time, suffer from selection bias, and are less helpful for developing countries to identify how effectively to improve the quality of local governance (see also Kurz and Schrack, 2007). Critics argue that indicators are used by donors to exclude or justify denial of aid, and set conditionality for assistance to developing countries. Kaufmann, Kraay, and Mastruzzi (2007a, 2007b), however, had partially accepted some weaknesses but argued that the indicators are developed through a transparent process, are available across many countries over time, and are of high quality, accurate and specific. Irrespective of the debates, the governance indicators are widely used by academics and practitioners to examine the governance performance and analyze the link between governance and other socio-economic issues, especially economic growth and development (Gisselquist, 2012).

\subsection{The Human Development}

The premise that human development is more than just economic development and is a process for enlarging people's choices led to the emergence of the human development indicators (UNDP, 1990). UNDP (2013) also argued that "people and their capabilities should be the ultimate criteria for evaluating the development level of a country along with economic growth."

HDI is a composite of three indicators that measures longevity, knowledge, and income (UNDP 1990). Accordingly, information about life expectancy at birth measures longitivity; mean years of schooling, and the expected year of schooling measures knowledge; and GNI per capita (PPP in USD) measures income (Ibid). Based on the information, the calculated index will assign a value between 0 and 1 for each country and make cross-country comparisons.

HDI has been used since 1990 by the United Nations Development Program (UNDP), which produces every year the Human Development Report (HDR). The three indicators and the composite index have been used by academicians and practitioners to measure countries' human development performances and progress as well as making comparisons among countries of the world.

Like the good governance indicators, there were critics on the use of the human development index. Some claim that the index depicted an oversimplified view of human development, considered only a few indicators derived from data of low quality, and based on arbitrary weighting scheme of factors. Others argue that HDI used wrong variables that cannot reflect the idea of human development correctly and ignored important constructs like subjective wellbeing or happiness, political freedom, human rights, access to safe water, and fresh air (McGillivray and White, 1993; Blanchflower and Oswald, 2005). Irrespective of the comments, however, HDI has been used for nearly three decades and the critics have not undermined the use of the index to measure countries' human development performance (Cahill, 2005). 


\section{The Empirical Literature on the Link Between Good Governance and Human Development}

The literature on good governance and human development shows that there are studies that analyzed the relationship between human development, governance, and other economic, social, and political issues. The available studies, which the author of this paper has access, can be categorized into three sets.

a) The first set of studies links human development with economic growth and analyze the associations among the human development indictors. A case in point is Bundala (2012) study on the relationship between human development and economic growth. Taking a sample of 40 countries and using a multivariate multiple regression model and based on the year 2011 scores of the human development index, the study found out that there is a strong relationship between human development and economic growth. The study, however, indicated that such a relationship starts after a country attained a certain level of human development. Another study by Eren et al. (2014) also examined the relationship between human development indicators. The study, which used various regression models, argued that life expectancy at birth, expected years of schooling, labor force participation rate, and GDP per capita have statistically significant effects on the level of human development.

b) The second set of studies is on the relationship between good governance and economic issues. Kurtz and Schrank (2007) showed that government effectiveness does not matter for economic growth. AlBassam (2013), on the other hand, indicated during the time of economic crises, the relationship between economic growth and the quality of governance highly depended on levels of human development and on indicators used to capture the quality of governance. A study on factors that contributed to Africa's Economic Growth by Mijiyawa (2013), however, showed governance effectiveness to be one of the factors that contributed to economic growth. The later study provides six crucial factors contributing to economic growth, which included: investment, private sector access to credit, government effectiveness, exports, and the share of agriculture value-added in GDP. The importance of governance effectiveness is also attributed to the attraction of foreign direct investment. Asongu (2019), using panel regression model and assessing the drivers of FDI in BRICS (Brazil, Russia, India, China \& South Africa) and MINT (Mexico, Indonesia, Nigeria \& Turkey) countries for the period 2001-2011, found out the importance of governance reforms in both current and future FDI location decisions.

c) The third set of studies is on the association between governance and human development in Europe and Africa. The study on Europe by Keser and Gökmen (2017) is comprehensive as it used panel data between the years 2002-2012 for 33 member and candidate countries of the European Union (EU). The analysis concluded that at least three of the governance indicators: government effectiveness, regulatory quality, and the rule of law had significant positive coefficients suggesting that better governance performance for any country provides better human development performance. The study on sub-Saharan Africa by Davis (2017) used the one year data for scores of good governance indicators (2014), the human development index (2013), the non-income human development index (2012), and 
the multi-poverty indicator intensity of deprivation (2010) as well as the percentage of population below the national poverty line (2012). The finding shows that the measures of good governance are related to the improvement of human development. Indicating the difficulty of identifying the governance indicators that are most related to changes in the measures of human development and quality of life. Nonetheless, this study suggested that government effectiveness could be the most important of the six good governance indicators in increasing human development in sub-Saharan Africa.

\section{The Data and Empirical Framework}

In order to measure the relationship between good governance and human development, this study used two sets of data - the six World Bank governance indicators (WGI) and the human development index (HDI). The data for the WGIs and HDI are publically available from the website of the World Bank and the UNDP, respectively. For both sets of indicators, this study used the data from 2000 - 2018. The 2001 information is omitted in the analysis since there is no WDIs for the same year. After matching the data periods and country names for the available data, the final selected data for the study covers 18 years and 49 countries out of the 54 African countries. The five countries, namely - Eretria, Guinea-Bissau, Nigeria, Somalia, and South Sudan - are not included in the study due to a lack of complete data for the years indicated on the six governance indicators.

This study used descriptive statistics and a panel regression in the analysis, measurement, and identification of the association between governance and human development in 49 African countries during the period (2000-2018) using a statistical software - Eviews 10.

The independent variables are the six world governance indicators (WGIs) labeled as CC (control of corruption), GE (government effectiveness), PS (political stability and absence of violence/terrorism), RQ (regulatory quality), and RL (the rule of law) VA (voice and accountability). The dependent variable is the human development index labeled as HD. The study will use the panel data regression model as panel data estimation is better to identify and measure the effects of independent variables on dependent variables (Batlag, 2005). Accordingly, the two panel regression data models - the Fixed Effect and Random Effect models - are used to compute the regression values. From these two models, the better model that explains the relationship will be selected using the Hausman Test. Since the variables in the regression model have different measurement units ( HDI: 0.00-1.00 point) and World Governance Index ( (-)2.5 - (+)2.5), the data are converted into logarithmic panel data. The two panel regression models are as follows:

a) Fixed Effect Model

$$
\ln H D i t=\beta 0 i+\beta 1 \ln C C i t+\beta 2 \ln G E i t+\beta 3 \ln P V i t+\beta 4 \ln R Q i t+\beta 5 \ln R L i t+\beta 6 \ln V A i t+u i t
$$

b) Random Effect Model

$\ln H D i t=\beta 0 i+\beta 1 \ln C C i t+\beta 2 \ln G E i t+\beta 3 \ln P V i t+\beta 4 \ln R Q i t+\beta 5 \ln R L i t+\beta 6 \ln V A i t+\varepsilon i+$ uit 
Where:

InHDit: the natural logarithm of human development for country i during the period $\mathrm{t}$;

InCCit: the natural logarithm of control of corruption for country i during the period $t$;

lnGEit: the natural logarithm of government effectiveness for country i during the period t;

InPSit: the natural logarithm of political stability for country i during the period t;

InRLit: the natural logarithm of the rule of law for country i during the period $t$;

InRQit: the natural logarithm of regulatory quality for country i during the period t;

InX1it: the natural logarithm of voice and accountability for country i during the period $\mathrm{t}$;

$\varepsilon i$ : the random error for each country;

uit: the random error from the regression model

\section{The Result of the Descriptive Statistical Analysis}

The analysis starts with a simple descriptive breakdown of the average values and the changes in good governance indicators and the human development index over time.

Table 1. Descriptive statistics

\begin{tabular}{|l|l|l|l|l|l|l|l|}
\hline Variable & $\begin{array}{l}\text { Sample } \\
\text { size }\end{array}$ & Min value & $\begin{array}{l}\text { Max } \\
\text { value }\end{array}$ & Mean & Median & $\begin{array}{l}\text { Standard } \\
\text { deviation }\end{array}$ & $\begin{array}{l}\text { Coefficient } \\
\text { of } \\
\text { Variation }\end{array}$ \\
\hline CC & 882 & -1.826361 & 1.216737 & -0.586038 & -0.657849 & 0.596528 & 38.27924 \\
\hline GE & 882 & -1.891929 & 1.056994 & -0.686501 & -0.697260 & 0.598022 & 36.26998 \\
\hline PV & 882 & -2.699193 & 1.282060 & -0.478552 & -0.333022 & 0.862538 & 40.42896 \\
\hline RL & 882 & -2.008507 & 1.077130 & -0.628022 & -0.645249 & 0.607772 & 37.43956 \\
\hline RQ & 882 & -2.278996 & 1.127270 & -0.632595 & -0.594586 & 0.574606 & 37.3481 \\
\hline VA & 882 & -2.000251 & 0.997744 & -0.587404 & -0.664658 & 0.708297 & 38.25192 \\
\hline HD & 882 & 0.253000 & 0.801000 & 0.508438 & 0.489000 & 0.119194 & 23.44 \\
\hline
\end{tabular}

Table 1 provides the sample size, the minimum, and maximum values, as well as the mean, the median, standard deviation, and coefficient of variation. Accordingly, the value of the standard deviation is higher than the mean for all the variables, and the difference between the maximum and minimum (range) is substantial. The coefficient of variation indicates that the data suffers from the existence of some extreme values. One possible reason for such considerable variation can be due to the difference in characteristics of the countries' overtime periods. This situation could indicate the appropriateness of the Fixed effect or the Random effect model.

Table 1 also shows that Africa's average performance in all governance indicators was not impressive. On the WGI scale of -2.5 to 2.5 (or converted into a scale of $0-100 \%$ ) the average scores from 2000 to 2018 for the six indicators were: voice and accountability $(-0.58$ 
or $38.2 \%)$; political stability $(-0.47$ or $40.4 \%)$; governance effectiveness (-0.68 or $36.2 \%)$; regulatory quality (-0.63 or $37.3 \%)$; rule of law ( -0.62 or $37.4 \%)$; and control of corruption $(-0.58$ or $38.2 \%)$. These values show that the average score for all the 49 African countries is below 50\%. On the other hand, the average human development index between 2000 and 2018 for all the countries was $50.8 \%$.

In addition to the figures in Table 1 , Annex 1 provides more information on the 18 years average score for each country, as well as the average change in both the WGI and HDI calculated using a one-year moving average. Accordingly, during the 18 years, the average growth rate for all the governance indicators was minimal, and for some of the indicators, the average growth was negative. Using one year moving average, the average growth rates for all the countries during the 18 years were: $0.72 \%$ (voice and accountability); $-3.99 \%$ (political stability), $-0.03 \%$ (governance effectiveness); $0.20 \%$ (regulator quality); $0.49 \%$ (rule of law) and $0.14 \%$ (control of corruption). Although very small, this shows that there were positive improvements in the four indicators: voice and accountability, the rule of law, regulatory quality, and control of corruption. On the other hand, the improvements in political stability and governance effectiveness were negative. The average change for HDI was $1.45 \%$, which is relatively better than the governance indicators. The following discussion provides a descriptive analysis of the changes in the dependent and independent variables based on the values calculated for each country in Appendix 1.

a) Voice and accountability: The average score for voice and accountability indicator for the 49 Africa countries under study ranges from 13\% to 67\%. There are only 11 countries with positive average scores or above $50 \%$, and the rest 38 countries scored below $50 \%$. Using the -2.5 to 2.5 WGI scale (or converted to $0-100 \%$ scale), the three countries that have high positive scores are Mauritius (.850 or 67\%), cape Verdi (.845 or 66.9\%), and South Africa (.636 or 62.7\%). The three countries with the lowest voice and accountability score are Equatorial Guinea ( -1.83 or $3.3 \%)$, Sudan $(-1.73$ or $15.4 \%)$, and Libya (-1.61 or $17.8 \%)$. Improvements, measured using the one-year moving average, in voice and accountability performance in Africa, have been deficient. The three countries that showed relative improvement during the 18 years were Sierra Léon $(5.11 \%)$, Tunisia $(4.81 \%)$, and Liberia $(4.36 \%)$. Countries that showed a decline in their scores were Equatorial Guinee (-1.63\%), Djibouti (-1.79\%), and Chad (-2.07\%). Although the average improvement rate is minimal, from 2000-2018, positive average improvement was recorded in 29 countries, while the rest 20 countries showed a decline in their voice and accountability performances.

b) Political stability: The average score of political stability ranged from $6.06 \%$ (Sudan) to $70.4 \%$ (Botswana). There were 11 countries with positive average scores and 38 countries with negative average scores. On the -2.5 and 2.5 scales ( or $0-100 \%$ scale), the three countries with relatively higher average scores are Botswana (1.02 or $70.4 \%)$, Mauritius ( 0.90 or $68 \%)$ and Cape Verdi $(0.83$ or $66.6 \%)$. The three countries with negative average scores are the Central African Republic (-1.844 or 13.1\%), Congo Democratic Republic $(-2.174$ or $6.5 \%)$, and Sudan $(-2.196$ or $6.1 \%)$. The percentage change in the average growth of political stability was minimal, except for three countries that showed better 
growth in political stability. The average growth for the Democratic Republic of Congo was $141.08 \%$; for Guinea, it was $27.87 \%$, and for Liberia, it was $16.61 \%$. On the other hand, a substantial decline in the average growth of political stability was recorded in the Central African Republic (-41.48\%), Sudan (-118.55\%), and Burundi (-249.94\%). During the 18 years, 25 countries recorded positive average improvement in political stability, while 22 countries showed a decline in average scores of political stability.

c) Government effectiveness: The Average governance effectiveness indicator was only positive for seven countries, while it was negative or below $50 \%$ for 42 countries. On the WGI scale of -2.5 and 2.5 (or $0-100 \%$ ), the highest-scoring countries were Mauritius $(0.789$ or $65.8 \%)$ Botswana $(0.512$ or $60.3 \%)$ and South Africa $(0.468$ or $59.4 \%)$. The three countries that had negative average scores were Central Africa Republic (- 1.548 or $19 \%$ ), Comoros (-1.555 or 18.9\%), and Democratic Republic of Congo (-1.63 or $17.5 \%)$. The average growth from 2000 to 2018 was less than $4 \%$. The highest positive average percentage change was recorded for Liberia (3.34\%), Democratic Republic of Congo (3.34\%), and Rwanda (2.90\%), while the decline in governance effectiveness was observed for Libya (-3.66\%) and Chad (-3.16\%). During the period, only 21 countries showed positive average growth, while 28 countries had negative average growth.

d) Regulatory quality: Regulatory quality indicators were positive or above $50 \%$ for four countries out of the 49 African countries. On the scale of -2.5 and 2.5, (or $0-100 \%$ ) these countries included Mauritius (0.798 or 66\%), Botswana $(0.562$ or $61.2 \%)$, South Africa ( 0.449 or $59 \%$ ), and Namibia $(0.081$ or $51.6 \%)$. On the other have the 45 African countries had negative scores, and the three lowest scoring countries were Democratic Republic of Congo (-1.47 or 20.6\%), Libya (-1.649 or 17\%), and Zimbabwe (-1.89 or $12 \%)$. The average growth rate for regulatory quality is also low and ranges from $-4.23 \%$ (Libya) and 7.87\% (Democratic Republic of Congo). Out of the 49 countries under study, 38 countries showed a decline in average growth, and 11 countries observed positive average growth.

e) Rule of Law: The rule of law indicator shows that seven countries had positive average scores or above $50 \%$, while the rest 42 countries had negative average scores. On the scale of -2.5 and 2.5, (or $0-100 \%$ ), the three countries that had the highest positive scores were: Mauritius (0.918 or $68.4 \%$ ), Botswana (0.62 or 62.4\%) and Cabo Verde ( 0.50 or 60.1$)$; and the three countries that had lowest scores were Central African Republic (- 1.50 or $19.9 \%$ ), Zimbabwe (-1.61 or $17.2 \%)$, and Democratic Republic of Congo (-1.64 or 17.8\%). During the period from 2000 to 2018, the average growth rate on the rule of law indicator was not impressive. Twenty-six countries showed positive growth, and the rest 23 countries observed negative growth. The highest average growth rates were for Angola (7.72\%), Rwanda (4.57\%), and Liberia (3.44), and the lowest growth rates were for Madagascar (-1.55\%), Sao Tome and Principal (-1.66) and Libya $(-3.80 \%)$.

f) Control of Corruption: The data on control of corruption revealed that only eight countries had positive scores, and the rest 41 countries had negative scores. On the scale 
of -2.5 and 2.5, (or $0-100 \%$ ), the highest-scoring countries were Botswana (0.93 or $68.7 \%$ ), Cabo Verdi (0.78 or $65.6 \%$ ), and Seychelles (0.45 or $58.9 \%)$. The countries that scored below $50 \%$ or negative were Chad (-1.36 or $22.7 \%)$, Democratic Republic of Congo (-1.39 or $22.3 \%$ ), and Equatorial Guinee (-1.59 or $18.3 \%)$. The average change during the period 2000 - 2018 was minimal and ranges from $-2.97 \%$ (Libya) to $4.61 \%$ (Liberia). Twenty-eight countries showed positive change on their average score, and the rest 21 countries regressed.

g) The Human Development Index: Out of the 49 African countries, 21 countries scored more than 50\%. The highest performing country in African is Seychelles (75.6\%). The lowest-performing country is Niger $(31.65 \%)$. The highest average growth in the human development index was $3.05 \%$ (Ethiopia). The only country that showed negative growth in the human development index was Libya $(-0.13 \%)$.

The descriptive analysis shows that countries in crisis are scoring poor in many of the governance indicators and the human development index. A case in point is Libya, a country that has a failed state and has a negative average growth or/and scores in human development, the rule of law, regulatory quality, government effectiveness, control of corruption, and voice and accountability. Other countries in crises like Niger, Democratic Republic of Congo, Sudan, Chad, and the Central African Republic showed negative scores in many of governance indicators. On the other hand, the four countries with stable governments Mauritius, Cabo Verdi, Botswana, and Namibia - had both high scores in the six governance indicators and the human development index. Countries like South Africa had also showed strong scores in some of the governance indicators and high scores in the human development index.

The descriptive analysis showed the existence of relationships between the governance indicators and human development indicators. Nevertheless, the analysis cannot show which governance indicators have a significant relationship with the human development index. Thus the panel regression model will be used to find out the governance indicators that have a significant association with the human development index.

\section{Result of the Panel Regression Analysis}

As indicated above, using the panel data regression analysis, this study will find out the indicators of good governance that are linked or associated with the human development index in 49 African countries for 2000-2018. In so doing, first, the Unit Root Test analysis will test whether the panel data set is stationary or not. Secondly, the Fixed Effect and Random Effect models will be run using EViews10 software. Lastly, the Hausman Test will be done to select the best model that explains the relationship.

\subsection{The Unit Root Test}

The initial step in the panel regression analysis is to check whether all series in the panel regression model is stationary or not. As pointed by Baltagi (2005), the panel unit root test must be employed to ensure whether the variables are stationary or not. This test is mainly done because non-stationary variables could lead to spurious regressions in regression 
analysis. Following the literature (Keser \& Gökmen, 2017), this study will use the two types of tests - the Common and Individual Unit Root Tests. The Common Unit Root Test is the Levin, Lin, and Chu (LLC) Test, which assumes that the persistent parameters are common across the cross-section. The other three Individual Unit Root Tests include the IPS, Fisher-ADF, and Fisher-PP tests. These three tests assume that the persistent parameters freely move across the cross-section. The null hypothesis is that there is a unit root process, and the alternative hypothesis is no unit root test, or the process has stationarity. Table 2 provides the result.

Table 2. Panel unit test summary

\begin{tabular}{|l|l|l|l|l|}
\hline \multirow{5}{*}{} & $\begin{array}{c}\text { The Common } \\
\text { Unit Root Test }\end{array}$ & \multicolumn{4}{l|}{ The Individual Unit Root Tests } \\
\cline { 2 - 5 } & $\begin{array}{c}\text { Levin. } \\
\text { Lin\&Chu t }\end{array}$ & $\begin{array}{l}\text { Lm, Peasaran and } \\
\text { Shin W-stat }\end{array}$ & $\begin{array}{l}\text { ADF-Fisher } \\
\text { Chi-Square }\end{array}$ & $\begin{array}{l}\text { PP } \\
\text { Chi-Square }\end{array}$ \\
\hline $\operatorname{lnCC}$ & -2.04106 & -2.862894 & 133.888 & 175.579 \\
& $(0.0206)$ & $(0.0043)$ & $(0.0094)$ & $(0.0000)$ \\
\hline $\ln$ GE & -4.03406 & -3.07872 & 156.976 & 246.298 \\
& $(0.0000)$ & $(0.0010)$ & $(0.0001)$ & $(0.0000)$ \\
\hline $\ln \mathrm{PV}$ & -11.30007 & -9.46897 & 259.193 & 502.824 \\
& $(0.0113)$ & $(0.0000)$ & $(0.0000)$ & $(0.0000)$ \\
\hline $\ln \mathrm{RL}$ & -1.97356 & -12.0749 & 329.64 & 302.332 \\
& $(0.0242)$ & $(0.0000)$ & $(0.0000)$ & $(0.0000)$ \\
\hline $\ln \mathrm{RQ}$ & -6.7915 & -11.5872 & 315.229 & 214.482 \\
& $(0.0000)$ & $(0.0000)$ & $(0.0000)$ & $(0.0000)$ \\
\hline $\ln \mathrm{VA}$ & -4.09666 & -4.2323 & 177.582 & 299.065 \\
& $(0.0000)$ & $(0.0000)$ & $(0.0000)$ & $(0.0000)$ \\
\hline $\ln \mathrm{HD}$ & -13.5794 & -3.44065 & 169.996 & 882.44 \\
& $(0.0000)$ & $(0.0003)$ & $(0.0000)$ & $(0.0000)$ \\
\hline
\end{tabular}

In Table 2, the probabilities (which are in parenthesis) for Fisher tests are computed using an asymptotic Chi-square distribution. All other tests assume asymptotic normality. Table 2 gives the stability of all the variables of the study at their original level and first difference level. The P-values of all the variables are less than the absolute value ( $\mathrm{p}$-value $>\alpha=0.05$ ). Based on these test values, it is possible to reject the null hypothesis, which states there is a unit root process. As the test shows there is a stationary process, it is accepted to apply panel regression model to determine the relationship between dependent and independent variables.

\subsection{Results of the Fixed Effect and Random Effect Models}

The panel analysis of good governance on human development is conducted using fixed and random effect models. As indicated earlier, this study uses Eviews 10 statistical software to analyze the link between the independent variables - the governance indicators and the dependent variable - the human development index. Table 3 provides as follows. 
Table 3. Fixed and random effect models summary

\begin{tabular}{|c|c|c|c|c|c|c|c|c|}
\hline & \multicolumn{4}{|c|}{ Fixed Effect Model } & \multicolumn{4}{|c|}{ Random Effect Model } \\
\hline & Coefficient & Std.err & t-test & p-value & Coefficient & Std.err & t-test & p-value \\
\hline constant & 3.377976 & 0.127651 & 26.46265 & 0.0000 & 3.355083 & 0.12016 & 27.92168 & 0.0000 \\
\hline $\operatorname{lnCC}$ & -0.080361 & 0.035708 & -2.250504 & 0.0247 & -0.06523 & 0.034945 & -1.86668 & 0.0623 \\
\hline $\operatorname{lnGE}$ & -0.179122 & 0.032956 & -5.465101 & 0.0000 & -0.149296 & 0.032346 & -4.615584 & 0.0000 \\
\hline $\operatorname{lnPV}$ & 0.072864 & 0.013375 & 5.547114 & 0.0000 & 0.055133 & 0.01218 & 4.52636 & 0.0000 \\
\hline $\operatorname{lnRL}$ & 0.23275 & 0.033754 & 6.89547 & 0.0000 & 0.24894 & 0.033412 & 7.450539 & 0.0000 \\
\hline $\operatorname{lnRQ}$ & 0.080741 & 0.025869 & 3.121212 & 0.0190 & 0.053374 & 0.02533 & 2.107159 & 0.0354 \\
\hline \multirow[t]{2}{*}{$\operatorname{lnVA}$} & 0.019925 & 0.022963 & 0.867738 & 0.3858 & 0.01022 & 0.022138 & 0.461625 & 0.6445 \\
\hline & \multicolumn{4}{|c|}{ Model summary Fixed effect } & \multicolumn{4}{|c|}{ Model summary Random Effect } \\
\hline $\mathbf{R}^{2}$ & & 0.885004 & & & & 0.111541 & & \\
\hline Adjusted $\mathrm{R}^{2}$ & & 0.877495 & & & & 0.105448 & & \\
\hline Std. Error & & 0.081963 & & & & 0.083673 & & \\
\hline $\mathrm{F}$ & & 117.862 & & & & 18.30846 & & \\
\hline P-value & & 0.0000 & & & & 0.0000 & & \\
\hline \multicolumn{9}{|c|}{ Correlated Random Effects - Hausman Test } \\
\hline \multirow{2}{*}{\multicolumn{2}{|c|}{ Test Summary }} & \multicolumn{2}{|r|}{ Statistic } & \multicolumn{2}{|c|}{ Chi-Sq. d.f. } & \multicolumn{3}{|l|}{ Probability } \\
\hline & & \multicolumn{2}{|c|}{42.904186} & \multicolumn{2}{|c|}{6} & \multicolumn{3}{|l|}{0.00000} \\
\hline
\end{tabular}

Table 3 gives the panel regression result of the fixed and random effect model as well as the Hausman test. The Hausman test statistic provides a p-value $=0.0000>\alpha=0.05$, which indicated that the fixed effects model is better than the random effect model to determine the relationship between governance and human development. The literature also shows that the fixed effect model is more advisable, especially in cross-country research, to control for possible omitted variable bias (Baltagi, 2005).

According to the fixed-effect model, the governance indicators, in general, have a significant positive association with human development. The six governance indicators combined interpreted $88.5 \%$ of the changes in human development, while the remaining $11.5 \%$ can be attributed to other factors (not included in the study). The value of adjusted $\mathrm{R}^{2}(0.877495)$ has little difference from $\mathrm{R}^{2}(0.885004)$, which indicates that the high $\mathrm{R}^{2}$ is not due to the increase in the number of independent variables but because of the importance of each variable in the model. As earlier pointed the descriptive statistics also gives indication that there is association between governance indicators and the human development index as most of the countries with relatively high scores of governance have high scores in human development index.

According to the results of the Fixed Effect model, it turns out that three governance indicators - Rule of Law, Regulatory quality, Political stability - are positively associated with human development at a statistically significant rate. The result also shows that there is a statistically significant but inverse relationship between Governance effectiveness and human development, as well as Control of Corruption and human development. One of the governance indicators - voice and accountability has no significant relations with the human development indicator. The finding of this study, however, differs from the limited studies conducted on Sub-saharan Africa that considers government effectiveness (Davis, 2017) to have a significant relation with human development. The result somehow agrees on the two variables of good governance - regulatory quality and the rule of law - that were found out to 
have significant association in Europe (Keser and Gökmen, 2017)

The finding from the Fixed Effect panel analysis shows that one of the governance indicators with the highest coefficient is the rule of law. As pointed above, the rule of law provides people's perception of the quality of contract enforcement, property rights, the police, and the courts and the likelihood of crime and violence. The critical importance of rule of law in human development is also supported by earlier studies. The widely known Capability-Building approach to development propounded by Sen (1999) maintained that the rule of law, which is an instrument for the expansion of freedom through securing civil and political rights, is the primary end and the principal means of freedom. As Pointed by Yu and Guernsey (2011), 'Multilateral institutions such as the World Bank and many policymakers throughout the world believe the rule of law promotes economic development.' Boettke and Subrick (2003) also asserted that 'The rule of law is an institutional feature that promotes economic development that, in turn, leads to increase in those capabilities that Nussbaum and Sen argue are necessary for living a human life.' Tamanaha (2011:4) also pointed out that the rule of law serves as an instrument for national development because it imposes legal limitations on and coordinates the acts of government officials as well as the behavior of citizens.

The second governance indicator that has a direct and significant relation to human development is regulatory quality. As indicated earlier, this indicator refers to the ability of the government to formulate and implement sound policies and regulations that permit and promote private sector development. Earlier studies also support this association between regulatory quality and human development. Djankov et. al (2002) pointed out that the countries with less limited, less democratic, and more interventionist governments regulate entry more heavily, even controlling for the level of economic development. Djankov et. al (2006) argued that government regulation of business is an essential determinant of growth. This study indicated that the relationship between more business-friendly regulations and higher growth rates is consistently significant in various specifications of standard growth models.

The third governance indicator that has a positive relationship with human development is Political stability and absence of violence. Earlier studies indicate that lack of political stability and the presence of violence breeds poor human development. Kim and Conceicao (2010) pointed out that 'conflict destroys accumulated physical and human capital, forces replacement of labor, and deteriorates institutional capacity. A country experiencing conflict cannot secure long term returns for investments in both physical and human capital, resulting in low investment in health and education (Ibid). In the same way, UNDP (2005) indicated that violent conflict is one of the most extreme forms of suppressing choices and advancing rights, therefore a major threat to human development.

\section{Conclusion}

By analyzing the longitudinal data from 2000 - 2018 for 49 African countries, this study examined the association between governance indicators and human development. The World Governance Indicators, developed by the World Bank, are used to measure good governance; 
and the HDI, developed by the UNDP, is used to measure human development. Both descriptive and panel regression analyses are used to analyze the link between governance indicators and human development index.

The descriptive analysis shows that countries that are scoring high in governance indicators are also scoring high in the human development index. The analysis also gave some indications that countries in crisis also have deficient scores in governance and human development index.

Africa's average performance in all governance indicators from 2000 - 2018 was between $36.2 \%$ and $40.4 \%$. Improvement in governance performance was not in general impressive. Using the one-year moving average, the calculated improvement rate for the eighteen years also showed a downward movement for political stability and governance effectiveness. Less than one percent but positive improvements were found out for regulator quality, the rule of law, and control of corruption. On the other hand, the average score for human development was $50.8 \%$, and the rate of the average change was $1.45 \%$. Both the average scores and the rate of improvement in governance and human development indicators were not impressive and indicate that African countries have to strive to improve their governance and human development performance.

The econometric analysis showed that the three governance indicators - the rule of law, regulatory quality, political stability, and absence of violence - are significantly and directly associated with the human development index. The finding revealed that governance effectiveness and control of corruption are inversely related to human development. Voice and accountability are not significantly related to human development. This result shows that countries should consider giving a relatively better emphasis on the three governance indicators that have positive and direct relations with human development. In general, this research shows the nexus between good governance and human development and lays the groundwork for future studies and policy considerations on improving governance and human development in Africa.

\section{References}

Agnello, L., Castro, V., Jalles, J. T., \& Sousa, R. M. (2017). The Impact of Fiscal Consolidation on Human Development. Journal of International Development, 30(3), 399-429.

Alam, M. R., Kitenge, E., \& Bedane, B. (2017). Government Effectiveness and Economic Growth. Economics Bulletin, $37(1), \quad 222-227$. http://www.accessecon.com/Pubs/EB/2017/Volume37/EB-17-V37-I1-P21.pdf

AlBassam, B. A. (2013). The Relationship Between Governance and Economic Growth During Times of Crisis. European Journal of Sustainable Development, 2(4), 1-18.

Arimah, B. C. (2004). Poverty Reduction and Human Development in Africa. Journal of Human Development, 3 399-418. https://www.equinetafrica.org/sites/default/files/uploads/documents/ARIpov.pdf 


\section{Macrothink}

Journal of Public Administration and Governance ISSN 2161-7104 2020, Vol. 10, No. 2

Arndt, C., \& Oman, C. (2006). Uses and Abuses of Governance Indicators. OECD: Development Center studies. Retrieved from https://www.la.utexas.edu/users/chenry/polec/2006/oecd/AE795835C8392A8111572211048 C64BBAF3DA2573E.pdf

Asongu, S. A., \& Nnanna, J. (2019). Foreign Aid, Instability, and Governance in Africa. Politics and Policy, 47(4), 807-848.

Asongu, S. A., \& Nwachukwu, J. C. (2016). Globalization and Inclusive Human Development in Africa. African Governance and Development Institute (AGDI) working paper, WP/16/049. Retrieved from https://mpra.ub.uni-muenchen.de/78140/1/MPRA_paper_78140.pdf

Baltagi, B. H. (2005). Econometric Analysis of Panel Data (Third Edition). John Wiley \& Sons Ltd, England.

Blanchflower, D. G., \& Oswald, A. J. (2005). Happiness and the Human Development Index: The Paradox of Australia. Australian Economic Review, 38(3), 307-318.

Boettke, P., \& Subrick, J. R. (2003). Rule of Law, Development, and Human Capabilities. Supreme Court Economic Review, 10, 109-126. https://www.jstor.org/stable/1147140?seq=1\#metadata_info_tab_contents

Bundala, N. (2012). Economic Growth and Human Development: A Link Mechanism: An Empirical Approach. MPRA Paper No. 47648. Retrieved from https://mpra.ub.uni-muenchen.de/47648/

Cahil, M. (2005). Is the Human Development Index Redundant? Eastern Economic Journal 31(1), 1-5.

Chikalipah, S., \& Makina, D. (2019). Economic growth and human development: Evidence from Zambia. Sustainable Development, 27(6), 1023-1033. https://www.researchgate.net/publication/332372496_Economic_growth_and_human_develo pment_Evidence_from_Zambia

Davis, T. J. (2017). Good governance as a foundation for sustainable human development in sub-Saharan Africa. Third World Quarterly, 38(3), 636-654.

Djankov, S., La Porta, R., Lopez-De-Silanes, F., \& Shleifer, A. (2002). The Regulation of Entry. The Quarterly Journal of Economics, CXVII(1), 1-37. https://scholar.harvard.edu/files/shleifer/files/reg_entry.pdf

Djankov, S., McLiesh, C., \& Ramalho, R. (2006). Regulation and Growth. Economics Letters, 92(3), 395-40.

Eren, M., Çelik, A. K., \& Kubat, A. (2014). Determinants of the Levels of Development Based on the Human Development Index: A Comparison of Regression Models for Limited Dependent Variables. Review of European Studies, 6(1), 10-23. http://www.ccsenet.org/journal/index.php/res/article/view/32501 
Fayissa, B., \& Nsiah, C. (2013). The Impact of Governance on Economic Growth in Africa.

The Journal of Developing Areas, 47(1), 91-108. https://www.researchgate.net/publication/265723317_The_Impact_of_Governance_on_Econ omic_Growth_in_Africa

Gisselquist, R. M. (2012). Good Governance as a Concept, and Why This Matters for Development. United Nations University Policy Working Paper No. 2012/30. Retrieved from https://www.wider.unu.edu/sites/default/files/wp2012-030.pdf

Ishiyama, J. (2019). Is Democracy Necessary for Good Governance? Social Science Quarterly, 100(6), 2188-2208.

Kaufman, D., Kraay, A., \& Zoido-Lobaton, P. (1999). Governance Matters. World Bank Policy Research Working Paper 2196. Retrieved from http://documents.worldbank.org/curated/en/665731468739470954/pdf/multi-page.pdf

Kaufmann, D., Kraay, A., \& Mastruzzi, M. (2007b). Growth and Governance: A Reply/Rejoinder. Journal of Politics, 69(2), 555-562.

Kaufmann, D., Kraay, A., \& Mastruzzi, M. (2007a). The Worldwide Governance Indicators Project: Answering the Critics. World Bank Policy Research Working Paper No. 4149. Retrieved from http://documents.worldbank.org/curated/en/979231468178138073/pdf/wps4149.pdf

Kaufmann, D., Kraay, A., \& Mastruzzi, M. (2008). Governance Matters VII: Aggregate and Individual Governance Indicators 1996-2007. The World Bank, Washington, D.C. Retrieved from http://info.worldbank.org/governance/wgi/pdf/GovernanceMattersVII.pdf

Keser, A., \& Gökmen, Y. (2017). Governance and Human Development: The Impacts of Governance Indicators on Human Development. Journal of Public Administration and Governance, $8(1)$ 26-39. http://www.macrothink.org/journal/index.php/jpag/article/view/12336

Khan, H. (2015). Good Governance and Human Development in Developing Countries with Special Reference to South Asia. In Governance in South, Southeast, and East Asia, 15,117-135 Retrieved from https://link.springer.com/chapter/10.1007/978-3-319-15218-9_8

Kim, N., \& Conceicao, P. (2010). The Economic Crisis, Violent Conflict, and Human Development. International Journal of Peace Studies, 15(1), 29-43.

Kurtz, M., \& Schrank, A. (2007). Growth and Governance: Models, Measures, and Mechanisms. Journal of Politics, 69(2), 538-554.

Kwon, H., \& Kim, E. (2014). Poverty Reduction and Good Governance: Examining the Rationale of the Millennium Development Goals. Development and Change, 45(2), 353-375.

McGillivray, M., \& White, H. (1993). Measuring development? The UNDP's human development index. Journal of International Development, 5(2), 183-192.

Mijiyawa, A. G. (2013). Africa's Recent Economic Growth: What Are the Contributing 


\section{Ml Macrothink}

Journal of Public Administration and Governance

ISSN 2161-7104

2020, Vol. 10, No. 2

Factors? African Development Review, 25(3), 289-302.

Rudra, P. P., \& Sanyal, G. S. (2011). Good governance and human development: Evidence form Indian States. Journal of Social and Development Science, 1(1), 1-8. https://ojs.amhinternational.com/index.php/jsds/article/view/622/622

Sen, A. (1999). Development as Freedom. Oxford University Press: New York.

UNDP. (1990). Human Development Report 1990. Oxford University Press, New York. http://hdr.undp.org/sites/default/files/reports/219/hdr_1990_en_complete_nostats.pdf

UNDP. (2005). Human Development Report 2005. International Cooperation at Cross Road. Retrieved from http://hdr.undp.org/sites/default/files/reports/266/hdr05_complete.pdf

UNDP. (2013). Human Development Report 2013: The Rise of the South: Human Progress in a Diverse World. Retrieved from http://hdr.undp.org/sites/default/files/reports/14/hdr2013_en_complete.pdf

World Bank. (1989). Sub-Saharan Africa: from crisis to sustainable growth. The World Bank, Washington, D.C. Retrieved from http://documents.worldbank.org/curated/en/498241468742846138/pdf/multi0page.pdf

Wunsch, J. S., \& Olowu, D. (eds). (1990). The Failure of The Centralized State: Institutions And Self-governance In Africa. Boulder, CO: Westview.

Yu, H., \& Guernsey, A. (2011). "What is the Rule of Law". Center for International Finance and Development. University of Iowa. Retrieved from http://freedom-school.com/law/what-is-the-rule-of-law.html

Appendix 1. Average score and average percentage changes *

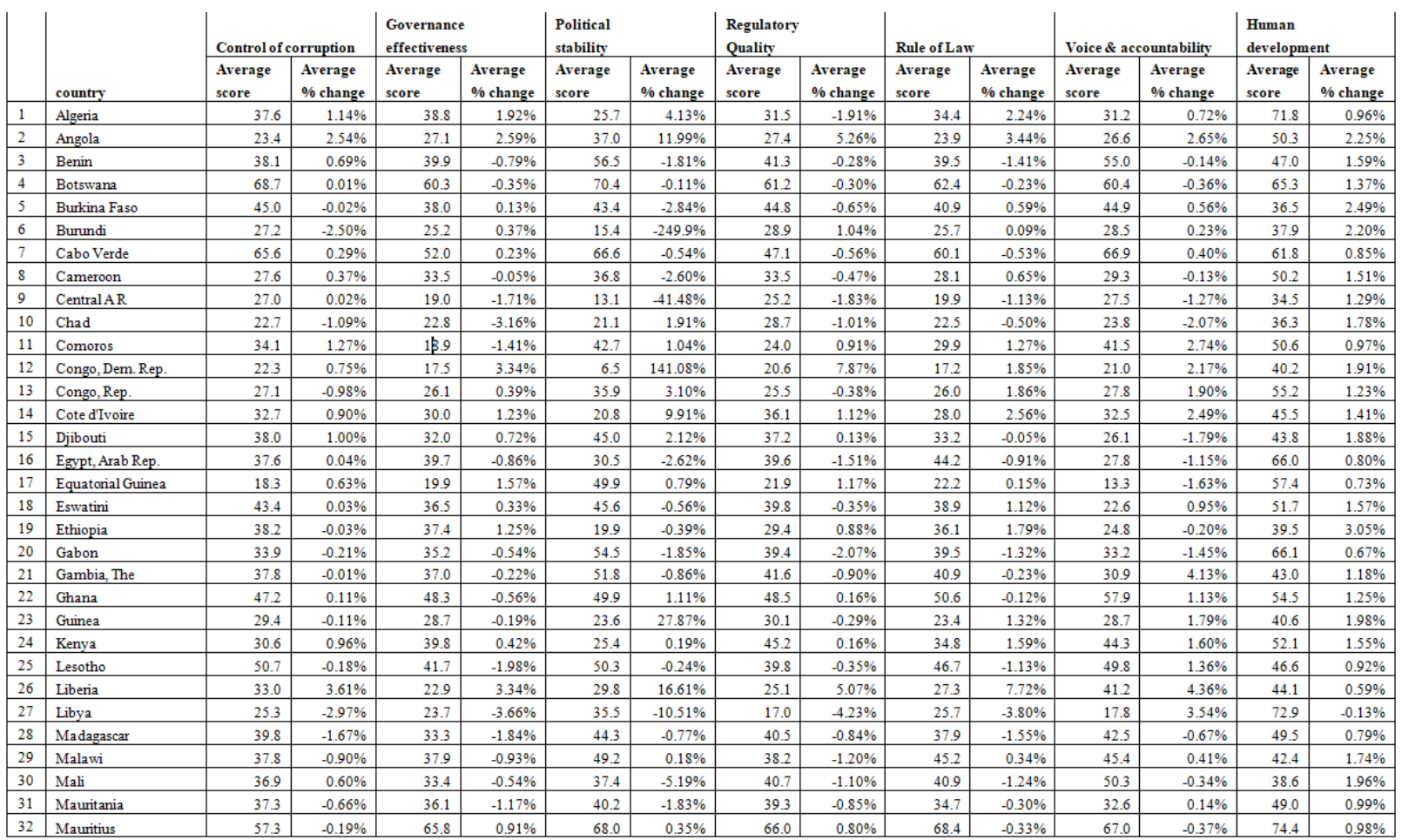




\begin{tabular}{|c|c|c|c|c|c|c|c|c|c|c|c|c|c|c|c|}
\hline 33 & Morocco & 44.6 & $-0.18 \%$ & 47.3 & $-0.30 \%$ & 42.1 & $-0.55 \%$ & 46.5 & $-0.44 \%$ & 47.0 & $-0.57 \%$ & 36.9 & $-0.48 \%$ & 61.4 & $1.43 \%$ \\
\hline 34 & Mozambique & 38.0 & $-1.02 \%$ & 37.6 & $-1.35 \%$ & 49.5 & $-1.16 \%$ & 40.1 & $-1.47 \%$ & 35.6 & $-1.02 \%$ & 46.2 & $-0.63 \%$ & 38.5 & $2.35 \%$ \\
\hline 35 & Namibia & 56.3 & $-0.32 \%$ & 52.6 & $-0.07 \%$ & 64.0 & $2.22 \%$ & 51.6 & $-0.64 \%$ & 53.9 & $0.18 \%$ & 52.7 & $-0.15 \%$ & 58.8 & $1.02 \%$ \\
\hline 36 & Niger & 35.5 & $1.11 \%$ & 35.5 & $1.14 \%$ & 34.6 & $-3.48 \%$ & 38.4 & $-0.13 \%$ & 37.9 & $0.61 \%$ & 43.1 & $-1.00 \%$ & 31.7 & $2.38 \%$ \\
\hline 36 & Rwanda & 52.9 & $3.10 \%$ & 45.6 & $2.90 \%$ & 39.5 & $8.21 \%$ & 43.6 & $3.63 \%$ & 41.7 & $4.57 \%$ & 24.7 & $2.47 \%$ & 46.0 & $2.78 \%$ \\
\hline 38 & Sao Tome and Principe & 47.0 & $0.15 \%$ & 36.4 & $-0.47 \%$ & 56.3 & $-0.84 \%$ & 35.0 & $-0.10 \%$ & 38.6 & $-1.66 \%$ & 54.9 & $-0.57 \%$ & 54.6 & $1.41 \%$ \\
\hline 39 & Senegal & 46.0 & $0.39 \%$ & 43.3 & $-0.15 \%$ & 45.9 & $1.62 \%$ & 45.9 & $0.02 \%$ & 46.5 & $-0.50 \%$ & 51.7 & $0.20 \%$ & 46.4 & $1.64 \%$ \\
\hline 40 & Seychelles & 58.9 & $0.58 \%$ & 54.6 & $0.99 \%$ & 65.7 & $-0.77 \%$ & 41.5 & $3.50 \%$ & 52.6 & $-0.49 \%$ & 51.9 & $0.44 \%$ & 75.7 & $0.70 \%$ \\
\hline 41 & Sierra Leone & 32.7 & $1.49 \%$ & 25.7 & $1.70 \%$ & 42.4 & $13.47 \%$ & 31.0 & $1.96 \%$ & 30.6 & $2.72 \%$ & 43.2 & $5.11 \%$ & 38.3 & $2.31 \%$ \\
\hline 42 & South Africa & 53.9 & $-1.28 \%$ & 59.4 & $-0.73 \%$ & 47.8 & $-0.03 \%$ & 59.0 & $-0.50 \%$ & 52.3 & $-0.66 \%$ & 62.7 & $-0.16 \%$ & 65.8 & $0.68 \%$ \\
\hline 43 & Sudan & 23.8 & $-1.82 \%$ & 23.2 & $-1.97 \%$ & 6.1 & $-118.5 \%$ & 22.1 & $-0.65 \%$ & 23.2 & $3.36 \%$ & 15.4 & $-0.39 \%$ & 46.5 & $1.38 \%$ \\
\hline 44 & Tanzania & 38.4 & $1.33 \%$ & 39.1 & $-0.99 \%$ & 42.6 & $1.20 \%$ & 41.2 & $-0.95 \%$ & 41.8 & $-0.53 \%$ & 44.7 & $0.36 \%$ & 47.5 & $1.73 \%$ \\
\hline 45 & Togo & 32.1 & $0.24 \%$ & 23.5 & $0.65 \%$ & 42.3 & $1.04 \%$ & 33.7 & $-0.01 \%$ & 32.8 & $0.54 \%$ & 30.5 & $1.78 \%$ & 46.7 & $1.10 \%$ \\
\hline 46 & Tumisia & 48.1 & $0.73 \%$ & 54.1 & $-1.22 \%$ & 44.0 & $-3.01 \%$ & 46.8 & $-0.93 \%$ & 49.4 & $0.69 \%$ & 38.0 & $4.81 \%$ & 70.7 & $0.73 \%$ \\
\hline 47 & Uganda & 31.5 & $-0.59 \%$ & 39.7 & $-0.53 \%$ & 29.7 & $2.83 \%$ & 46.5 & $-0.71 \%$ & 41.5 & $1.61 \%$ & 37.7 & $1.27 \%$ & 47.4 & $1.73 \%$ \\
\hline 48 & Zambia & 40.2 & $0.28 \%$ & 35.8 & $1.19 \%$ & 55.4 & $0.51 \%$ & 40.0 & $-0.36 \%$ & 42.0 & $0.45 \%$ & 44.8 & $0.35 \%$ & 52.0 & $1.92 \%$ \\
\hline 49 & Zimbabwe & 23.8 & $-0.92 \%$ & 25.5 & $-1.11 \%$ & 30.3 & $3.40 \%$ & 12.0 & $4.14 \%$ & 17.8 & $0.95 \%$ & 22.2 & $0.20 \%$ & 48.2 & $1.33 \%$ \\
\hline
\end{tabular}

*The average score is calculated by adding the 18 years scores of each indicator and dividing by 18 .

The average $\%$ change is the 18years average of the calculated one-year moving average score for all indictors.

\section{Copyright Disclaimer}

Copyright for this article is retained by the author(s), with first publication rights granted to the journal.

This is an open-access article distributed under the terms and conditions of the Creative Commons Attribution license (http://creativecommons.org/licenses/by/4.0/). 